\title{
Mixtures obtained by reacting trans $-( \pm)$-1,2-diaminocyclohexane with acetylacetone in the presence of simple cobalt(II) salts
}

\author{
Malachy McCann ${ }^{\text {a,*}}$, Sean Townsend a , Michael Devereux ${ }^{b}$, Vickie McKee ${ }^{\mathrm{c}}$, \\ Brian Walker ${ }^{\mathrm{d}}$ \\ ${ }^{a}$ Chemistry Department, National University of Ireland Maynooth, Maynooth, Co. Kildare, Ireland \\ ${ }^{\mathrm{b}}$ Dublin Institute of Technology, Cathal Brugha Street, Dublin, Ireland \\ ${ }^{\mathrm{c}}$ Chemistry Department, Loughborough University, Loughborough, Leics., LE11 3TU, UK \\ 'School of Pharmacy, Queen's University, Belfast, BT9 7BL, UK
}

Received 12 March 2001; accepted 31 May 2001

\begin{abstract}
In the absence of a metal ion, racemic trans-1,2-diaminocyclohexane (trans $-( \pm) \mathrm{DCH})$ reacts with acetylacetone $(\mathrm{acacH})(1: 2.5$ mole ratio) to form the bisoxoenamine condensation product, boe (1). $\mathrm{CoCl}_{2} \cdot 6 \mathrm{H}_{2} \mathrm{O}$ and $\mathrm{Co}\left(\mathrm{ClO}_{4}\right)_{2} \cdot 6 \mathrm{H}_{2} \mathrm{O}$ each react with trans $-( \pm) \mathrm{DCH}$ in air to give complexes containing the oxidised $\mathrm{Co}(\mathrm{III})$ ion, $\left[\mathrm{Co}(( \pm) \mathrm{DCH})_{3}\right]^{3+}$, which does not subsequently react with added acacH to give a Schiff base complex. Mixtures of complexes are obtained from one-pot reactions involving trans $-( \pm) \mathrm{DCH}$, a simple $\mathrm{Co}(\mathrm{II})$ salt and acacH $\left(1: 1: 2.5\right.$ mole ratio). When $\mathrm{CoCl}_{2} \cdot 6 \mathrm{H}_{2} \mathrm{O}$ is used, the mixed-ligand $\mathrm{Co}(\mathrm{II})$ complex $\left[\mathrm{Co}(( \pm) \mathrm{DCH}) \mathrm{Cl}_{2}\right](4)$ precipitates first and, after a period of weeks, the $\mathrm{Co}(\mathrm{II})$ complex $(\operatorname{diazH})_{2}\left[\mathrm{CoCl}_{4}\right](5)\left(\mathrm{diazH}^{+}\right.$is a diazepinium cation), the $\mathrm{Co}(\mathrm{II})$ complex $\left[\mathrm{Co}(\mathrm{boe}) \mathrm{Cl}_{2}\right]_{n}(\mathbf{6})$ and the $\mathrm{Co}(\mathrm{III})$ complex $\left[\mathrm{Co}(\mathrm{acac})_{3}\right](7)$, co-crystallise from the mother liquor. Using $\mathrm{Co}\left(\mathrm{ClO}_{4}\right)_{2} \cdot 6 \mathrm{H}_{2} \mathrm{O}$ in the reaction with trans $-( \pm) \mathrm{DCH}$ and acacH also gives a mixture of products. Complexes 7, the $\mathrm{Co}(\mathrm{II})$ complex $\left[\mathrm{Co}_{2}(\mathrm{acac})_{4}\left(\mathrm{H}_{2} \mathrm{O}\right)_{2}\right]\left[\mathrm{Co}(\mathrm{acac})\left(\mathrm{H}_{2} \mathrm{O}\right)_{4}\right] \mathrm{ClO}_{4} \cdot \mathrm{EtOH}(\mathbf{8})$ and the $\mathrm{Co}(\mathrm{III})$ complex $\left[\mathrm{Co}(\mathrm{acac})_{2}( \pm) \mathrm{DCH}\right] \mathrm{ClO}_{4}(9)$ co-crystallise. Complexes 1, 5, 7, 8 and 9 were characterised using X-ray crystallography. The major difference between using $\mathrm{CoCl}_{2} \cdot 6 \mathrm{H}_{2} \mathrm{O}$ and $\mathrm{Co}\left(\mathrm{ClO}_{4}\right)_{2} \cdot 6 \mathrm{H}_{2} \mathrm{O}$ in reactions involving $( \pm) \mathrm{DCH}$ and acacH is that no $\mathrm{DCH} /$ acacH condensation products are identified in the product mixtures when the perchlorate salt is employed. (C) 2001 Elsevier Science Ltd. All rights reserved.
\end{abstract}

Keywords: trans-( \pm )-1,2-Diaminocyclohexane; Acetylacetone; Cobalt(II) salts; Schiff base complexes

\section{Introduction}

Condensation reactions involving $\beta$-diketones and $\alpha, \omega$-diamines can give a range of products depending on the experimental conditions $[1,2] .{ }^{1}$ For example, in Scheme 1, formation of the bisoxoenamine (a) is favoured in the $\mathrm{pH}$ range $6-10$, whereas diazepine (b) production occurs under either more acidic or more alkaline conditions. In Scheme 2 the anil (a) is stabilized when $\mathrm{R}=\mathrm{CH}_{3}$ because of steric effects.

* Corresponding author. Tel.: + 353-1-708-3767; fax: + 353-1-7083815 .

E-mail address: mmcann@may.ie (M. McCann).

${ }^{1}$ Representations of the keto-enol tautomers of diketones and imino enol-amino ketone tautomers of the Schiff bases are given in the forms presented in the various literature citations.
Diazepines are of significance in relation to the medicinally important 1,4-benzodiazepine tranquillizers [3]. trans-1,2-Diaminocyclohexane (trans-DCH) has frequently been used as the diamine in the production of diazepines and Schiff bases. For example, the structurally characterised compound, $(5 \mathrm{a} R, 9 \mathrm{a} R)-2,4-$ dimethyl-5a,6,7,8,9,9a-hexahydro- $1 H$-1,5-benzodiazepin e (Fig. 1), forms from the condensation of $(1 R, 2 R)$ trans-1,2-diaminocyclohexane with 4-amino-3-penten-2one [4]. Furthermore, chloride [5] and perchlorate [6] salts of 2,3-dihydro-1H-1,4-diazepinium cations have been prepared by condensing 1,2-diamines with acetylacetone $(\mathrm{acacH})$. Ultraviolet spectral measurements on the chloride salt, synthesised from trans $-( \pm) \mathrm{DCH}$ and acacH, indicated planarity of the two fused rings in the cation and suggested delocalisation of the $6 \pi$ electrons (Scheme 3). 
Condensing acacH with either trans- $(+)-\mathrm{DCH}$ or trans-(meso $)-\mathrm{DCH}$ in a 2:1 mole ratio gives the respective Schiff base ligands (Scheme 4) [7]. In the absence of $\mathrm{X}$-ray crystallographic studies, structural assignment of the product was based on spectroscopic data.

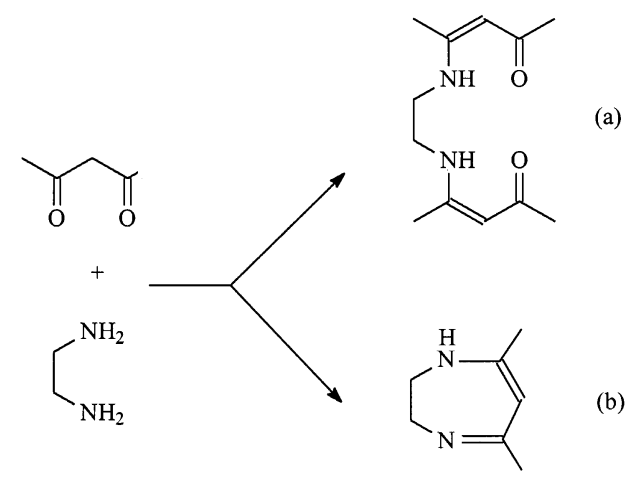

Scheme 1.

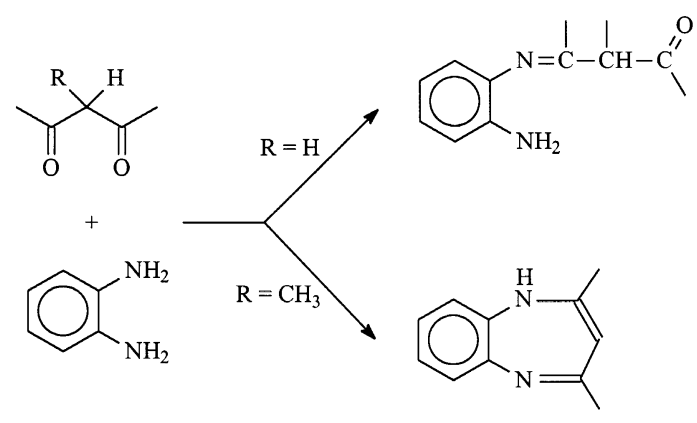

(a)

Scheme 2.<smiles>CC1=CC(C)=NC2CCCCC2N1</smiles>

Fig. 1. (5a $R, 9 \mathrm{a} R)-2,4-D i m e t h y l-5 \mathrm{a}, 6,7,8,9,9 \mathrm{a}-$ hexahydro- $1 H$-1,5-benzodiazepine.

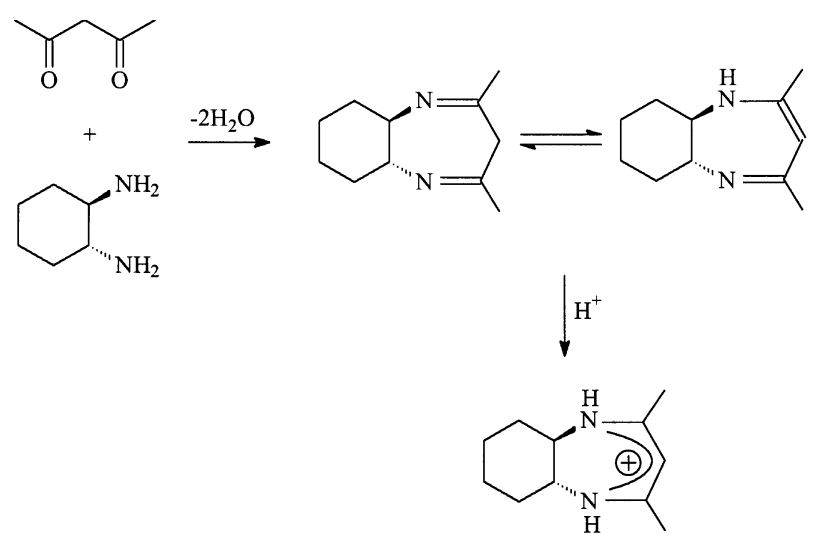

Scheme 3.

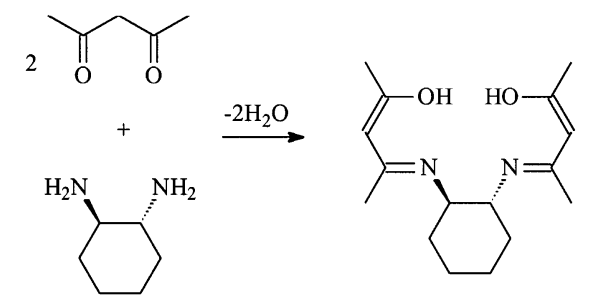

Scheme 4.

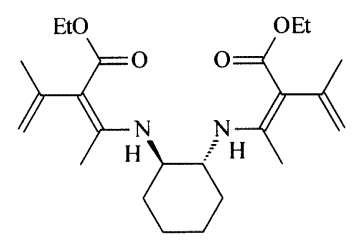

Fig. 2. Schiff base made from trans $-1 S, 2 S-(+)-\mathrm{DCH}$ and ethyl (ethoxymethylene)acetoacetate.

A family of Schiff bases was generated by reacting cis-1,2-diaminocyclohexane and resolved forms of trans-DCH with ethoxymethylene- $\beta$-carbonyls in a $1: 2$ mole ratio [8]. The Schiff base formed using trans$1 S, 2 S$ - (+)-DCH and ethyl (ethoxymethylene)acetoacetate was structurally characterised (Fig. 2) and a variety of $\mathrm{Ni}(\mathrm{II})$ and $\mathrm{Cu}(\mathrm{II})$ complexes was also prepared using the various bases.

Bailey et al. [1] noted that with Schiff bases derived from trans-DCH the bite sizes limit complex formation because of the steric constraint introduced by an unfavourable overlap between the cyclohexane bridge protons (on $\mathrm{C} 3$ and $\mathrm{C} 4$ ) and the methyl groups adjacent to the nitrogen of the Schiff base. With this in mind these workers used cis-DCH in preference to the trans isomer for the preparation of compartmental Schiff base ligands from $\beta$-triketones.

The present work focuses on the reactions of trans$( \pm) \mathrm{DCH}$ with acacH in the absence of and in the presence of $\mathrm{Co}(\mathrm{II})$ ions.

\section{Results and discussion}

trans $-( \pm) \mathrm{DCH}$ reacts with acacH in a 1:2.5 mole ratio to give the bisoxoenamine condensation product boe (1) in good yield. The X-ray crystal structure of $\mathbf{1}$ is shown in Fig. 3 (Table 1). Compound $\mathbf{1}$ is the keto form of the Schiff base enol tautomer illustrated in Scheme 4. The basic structural framework of $\mathbf{1}$ is similar to that of the condensation product shown in Fig. 2. The asymmetric unit contains two molecules and although the molecules are very similar, a search using PLATON [9] did not reveal any extra symmetry. Each molecule has two internal hydrogen bonds linking the amines to the terminal oxygen atoms on the same acac 'arm'. 
The reactions of trans $-( \pm) \mathrm{DCH}$ with $\mathrm{CoCl}_{2} \cdot 6 \mathrm{H}_{2} \mathrm{O}$ and $\mathrm{Co}\left(\mathrm{ClO}_{4}\right)_{2} \cdot 6 \mathrm{H}_{2} \mathrm{O}$ in a $3: 1$ mole ratio in air gave the respective oxidised $\mathrm{Co}(\mathrm{III})$ tris $-\mathrm{DCH}$ chloride and perchlorate salts, $\left[\mathrm{Co}(( \pm) \mathrm{DCH})_{3}\right] \mathrm{Cl}_{3} \cdot \mathrm{H}_{2} \mathrm{O}(2)$ and $[\mathrm{Co}(( \pm)-$

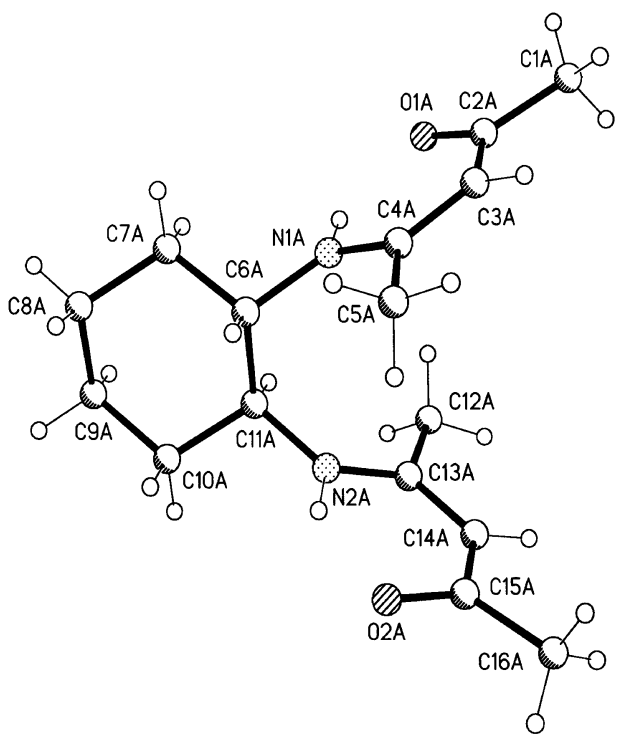

Fig. 3. Structure of boe (1).

Table 1

Selected bond lengths $(\AA)$ and angles $\left(^{\circ}\right)$ for 1

\begin{tabular}{llll}
\hline Bond lengths & & & \\
$\mathrm{O}(1 \mathrm{~A})-\mathrm{C}(2 \mathrm{~A})$ & $1.249(3)$ & $\mathrm{C}(11 \mathrm{~A})-\mathrm{N}(2 \mathrm{~A})$ & $1.452(3)$ \\
$\mathrm{C}(4 \mathrm{~A})-\mathrm{N}(1 \mathrm{~A})$ & $1.336(3)$ & $\mathrm{N}(2 \mathrm{~A})-\mathrm{C}(13 \mathrm{~A})$ & $1.335(3)$ \\
$\mathrm{N}(1 \mathrm{~A})-\mathrm{C}(6 \mathrm{~A})$ & $1.451(3)$ & $\mathrm{C}(15 \mathrm{~A})-\mathrm{O}(2 \mathrm{~A})$ & $1.249(3)$
\end{tabular}

Bond angles

$\mathrm{O}(1 \mathrm{~A})-\mathrm{C}(2 \mathrm{~A})-\mathrm{C}(3 \mathrm{~A}) \quad 121.8(3) \quad \mathrm{C}(13 \mathrm{~A})-\mathrm{N}(2 \mathrm{~A})-\mathrm{C}(11 \mathrm{~A}) \quad 129.9(2)$

$\mathrm{O}(1 \mathrm{~A})-\mathrm{C}(2 \mathrm{~A})-\mathrm{C}(1 \mathrm{~A}) \quad 119.5(3) \quad \mathrm{O}(2 \mathrm{~A})-\mathrm{C}(15 \mathrm{~A})-\mathrm{C}(14 \mathrm{~A}) \quad 122.9(3)$

$\mathrm{C}(4 \mathrm{~A})-\mathrm{N}(1 \mathrm{~A})-\mathrm{C}(6 \mathrm{~A}) \quad 129.4(2) \quad \mathrm{O}(2 \mathrm{~A})-\mathrm{C}(15 \mathrm{~A})-\mathrm{C}(16 \mathrm{~A}) \quad 118.9(3)$

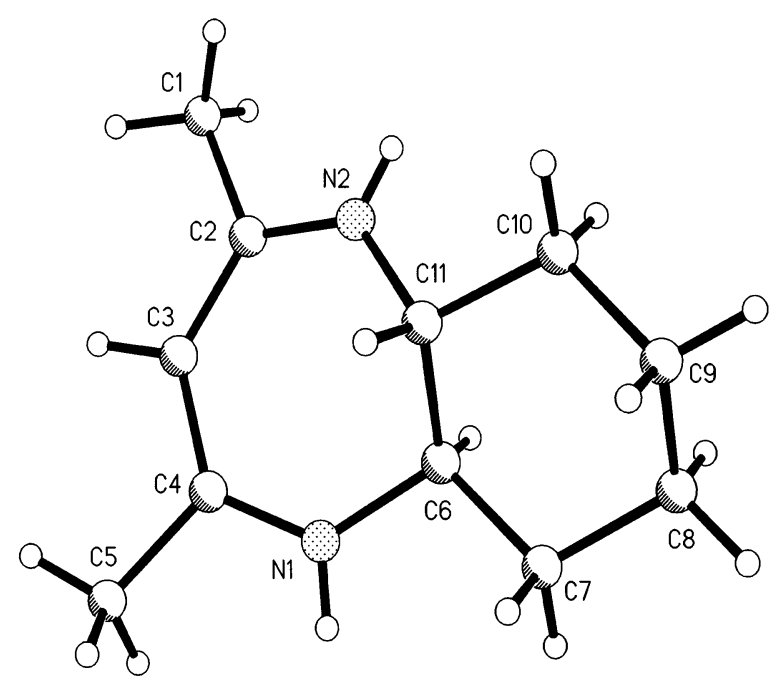

Fig. 4. Detailed structure of one of the $\operatorname{diazH}^{+}$cations in $\mathbf{5}$.
Table 2

Selected bond lengths $(\AA)$ and angles $\left(^{\circ}\right)$ for $\mathbf{5}$

\begin{tabular}{llll}
\hline $\begin{array}{l}\text { Bond lengths } \\
\mathrm{C}(2)-\mathrm{N}(2)\end{array}$ & & & \\
$\mathrm{C}(2)-\mathrm{C}(3)$ & $1.313(3)$ & $\mathrm{N}(1)-\mathrm{C}(6)$ & $1.459(3)$ \\
$\mathrm{C}(3)-\mathrm{C}(4)$ & $1.385(4)$ & $\mathrm{C}(6)-\mathrm{C}(11)$ & $1.536(4)$ \\
$\mathrm{C}(4)-\mathrm{N}(1)$ & $1.316(4)$ & & $1.456(4)$ \\
Bond angles & & & \\
$\mathrm{N}(2)-\mathrm{C}(2)-\mathrm{C}(3)$ & $125.0(3)$ & $\mathrm{N}(1)-\mathrm{C}(6)-\mathrm{C}(11)$ & $111.1(2)$ \\
$\mathrm{C}(4)-\mathrm{C}(3)-\mathrm{C}(2)$ & $131.1(3)$ & $\mathrm{N}(2)-\mathrm{C}(11)-\mathrm{C}(6)$ & $111.7(2)$ \\
$\mathrm{N}(1)-\mathrm{C}(4)-\mathrm{C}(3)$ & $126.8(3)$ & $\mathrm{C}(2)-\mathrm{N}(2)-\mathrm{C}(11)$ & $126.7(2)$ \\
$\mathrm{C}(4)-\mathrm{N}(1)-\mathrm{C}(6)$ & $128.0(3)$ & & \\
\hline
\end{tabular}

$\left.\mathrm{DCH})_{3}\right]\left(\mathrm{ClO}_{4}\right)_{3}(3)$. The anhydrous form of 2 , $[\mathrm{Co}(( \pm)$ $\left.\mathrm{DCH})_{3}\right] \mathrm{Cl}_{3}$, has previously been reported to form in a reaction in which $\mathrm{H}_{2} \mathrm{O}_{2}$ was employed as the metal oxidant [10]. Racemic and resolved forms of trans$\mathrm{DCH}$ have been used as a bidentate ligand for the synthesis of $\left[\operatorname{Ir}(\mathrm{DCH})_{3}\right]^{3+}$ and $\left[\mathrm{Co}(\mathrm{DCH})_{3}\right]^{3+}[10]$, whilst the racemic diamine was used to make the copper(II) complexes $\left[\mathrm{Cu}(( \pm)-\mathrm{DCH})_{3}\right]\left(\mathrm{ClO}_{4}\right)_{2} \cdot \mathrm{H}_{2} \mathrm{O}$ [11], $\left[\mathrm{Cu}(( \pm)-\mathrm{DCH})_{2}\left(\mathrm{ClO}_{4}\right)_{2}\right][11],\left[\mathrm{Cu}(( \pm)-\mathrm{DCH})_{2}\left(\mathrm{H}_{2} \mathrm{O}\right)_{2}\right]-$ $\mathrm{Cl}_{2}$ [12] and $\left[\mathrm{Cu}(( \pm)-\mathrm{DCH})_{2}\left(\mathrm{NO}_{3}\right)_{2}\right]$ [12]. The copper(II) complexes and some of the iridium(III) and cobalt(III) complexes were structurally characterised.

Unsuccessful attempts were made to use the DCH complexes $\mathbf{2}$ and $\mathbf{3}$ in the template synthesis of Schiff base complexes by subsequent condensation with acacH. Only unreacted starting materials were recovered when 2 and 3 were treated with acacH (1:6 mole ratio), emphasising the slow ligand exchange kinetics of Co(III) complexes containing $\mathrm{N}$-donor ligands [10]. In contrast to the kinetic inertness of such $\mathrm{Co}(\mathrm{III})$ complexes the nickel(II) ethylenediamine (en) complex, $\left[\mathrm{Ni}_{2}(\mathrm{en})_{4} \mathrm{Cl}_{2}\right] \mathrm{Cl}_{2}$, reacts with a $\beta$-diketone in the presence of a catalytic amount of pyridine to form a precipitate of the respective Schiff base complex [13].

$A$ one-pot reaction involving trans $-( \pm) \mathrm{DCH}$, $\mathrm{CoCl}_{2} \cdot 6 \mathrm{H}_{2} \mathrm{O}$ and acacH (1:1:2.5 mole ratio) produced firstly a precipitate of $\left[\mathrm{Co}(( \pm) \mathrm{DCH}) \mathrm{Cl}_{2}\right]$ (4) followed by the co-crystallisation of $(\operatorname{diazH})_{2}\left[\mathrm{CoCl}_{4}\right] \quad$ (5), $\left[\mathrm{Co}(\text { boe }) \mathrm{Cl}_{2}\right]_{n}(6)$ and $\left[\mathrm{Co}(\mathrm{acac})_{3}\right](7)$. When the experiment was repeated using a smaller amount of acacH $(9.37 \mathrm{mmol}$ instead of $23.67 \mathrm{mmol})$ the yield of 4 increased substantially and the yield of the mixture 5-7 decreased dramatically. Whereas samples 4-6 are $\mathrm{Co}(\mathrm{II})$ complexes, 7 is a $\mathrm{Co}$ (III) species. It is noteworthy that $\left[\mathrm{Co}(( \pm) \mathrm{DCH})_{3}\right] \mathrm{Cl}_{3} \cdot \mathrm{H}_{2} \mathrm{O}(2)$ was not recovered from reactions in which acacH featured as a starting material.

The X-ray crystal structures of 5, 6 and 7 were obtained. Complex 5 contains independent diazH $\mathrm{H}^{+}$ cations (Fig. 4, Table 2), formed from a 1:1 condensation of acacH with trans $-( \pm) \mathrm{DCH}$, and tetrahedral $\left[\mathrm{CoCl}_{4}\right]^{2-}$ anions. The charge on the cations is delo- 


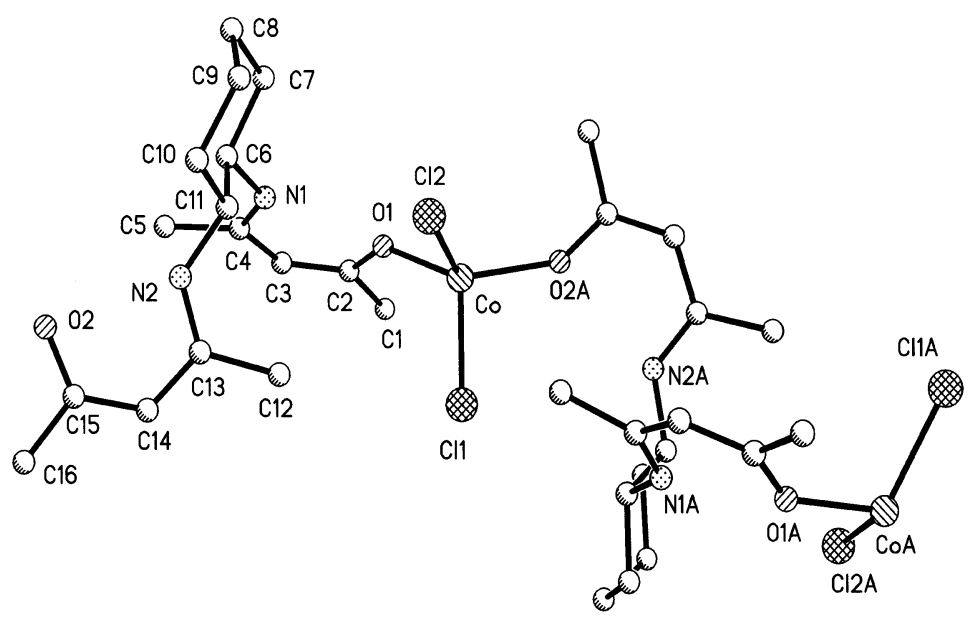

Fig. 5. A section of the polymer $\left[\mathrm{Co}(\text { boe }) \mathrm{Cl}_{2}\right]_{n}(\mathbf{6})$.

calised and the protons on both nitrogen atoms were located. Each proton is hydrogen-bonded to a $\left[\mathrm{CoCl}_{4}\right]^{-}$ anion. All of the bonds in the vinamidine $\mathrm{N} 1-\mathrm{C} 4-\mathrm{C} 3-$ $\mathrm{C} 2-\mathrm{N} 2$ moiety of the diazepine ring are shortened and this section of the ion is almost planar. Indeed, this portion of the ring is more planar than the corresponding section in the neutral diazepine illustrated in Fig. 1, the latter being described as 'pseudo-aromatic' [4]. There does not appear to be much difference in the apparent delocalisation between these cationic and neutral diazepine species. In contrast, for phenyl-substituted diazepines there is a striking difference between bond distances in neutral diazepine bases and in their corresponding cations [14]. Although the cations have a definite delocalised structure, the bonds in the vinamidine systems of the diazepine bases are alternatively single and double. Furthermore, whereas the cations are inherently symmetrical, the bases are not, and they can only achieve symmetry in solution by a very rapid 1,5-shift of a $\mathrm{H}$ atom between the 1- and 4-N atoms.

The bisoxoenamine Co(II) complex $\mathbf{6}$ is polymeric with the free oxygen donors of the neutral boe ligand $\mathbf{1}$ linking approximately tetrahedral cobalt ions, each also having two chloride ligands (Fig. 5, Table 3). The amine protons were located and their positions refined. As with the free ligand $\mathbf{1}$ there are hydrogen-bonds linking the amine and the neighbouring oxygen atoms (N1-O1 2.645(4), N2-O2 2.648(4) ̊). The X-ray crystal structure of the tris(acac) Co(III) complex 7 was the same as that previously reported in the literature [15].

The use of $\mathrm{Co}\left(\mathrm{ClO}_{4}\right)_{2} \cdot 6 \mathrm{H}_{2} \mathrm{O}$ in a one-pot reaction mixture incorporating trans $-( \pm) \mathrm{DCH}$ and acacH (1:1:2.5 mole ratio) gave some different products than the same reaction involving $\mathrm{CoCl}_{2} \cdot 6 \mathrm{H}_{2} \mathrm{O}$. These differences probably reflect the fact that $\mathrm{Cl}^{-}$is superior to $\mathrm{ClO}_{4}^{-}$as a competitive coordinating ligand. Complexes 7, $\left[\mathrm{Co}_{2}(\mathrm{acac})_{4}\left(\mathrm{H}_{2} \mathrm{O}\right)_{2}\right]\left[\mathrm{Co}(\mathrm{acac})\left(\mathrm{H}_{2} \mathrm{O}\right)_{4}\right] \mathrm{ClO}_{4} \cdot \mathrm{EtOH} \quad(8)$ and $\left[\mathrm{Co}(\mathrm{acac})_{2}( \pm) \mathrm{DCH} \mathrm{ClO}_{4}(9)\right.$ co-crystallised in the product mixture and single crystals of each were carefully separated and used for X-ray crystallographic studies.

In complex 8 (Figs. 6 and 7, Table 4) the asymmetric unit contains one $\left[\mathrm{Co}(\mathrm{acac})\left(\mathrm{H}_{2} \mathrm{O}\right)_{4}\right]^{+}$cation and half of each of two independent $\left[\mathrm{Co}_{2}(\mathrm{acac})_{4}\left(\mathrm{H}_{2} \mathrm{O}\right)_{2}\right]$ species, one perchlorate anion and one ethanol solvate (both of which are disordered). The perchlorate anion was modelled with two sets of oxygen atoms about a common $\mathrm{Cl}$ position; and the central carbon of the ethanol molecule was disordered over two sites. All of the metal ions are six-coordinate and bond distances and stoichiometry are consistent with the $\mathrm{Co}$ (II) oxidation state. Each cobalt ion in the $\left[\mathrm{Co}_{2}(\mathrm{acac})_{4}\left(\mathrm{H}_{2} \mathrm{O}\right)_{2}\right]$ dimers is coordinated to two cisoid bidentate $\mathrm{acac}^{-}$ligands and one water molecule; the coordination sphere is completed by a bridging oxygen atom from one of the bidentate $\mathrm{acac}^{-}$ligands coordinated to the second cobalt ion. Consequently, two of the $\mathrm{acac}^{-}$ligands are bidentate only while the other two also act as one-atom bridges between the metal ions. This is somewhat similar to the coordination found in the tetranuclear $\mathrm{Co}$ (II) complex $\left[\mathrm{Co}_{4}(\mathrm{acac})_{8}\right]$ [16]. The $\mathrm{Co}-\mathrm{Co}$ distances in $\left[\mathrm{Co}_{2}(\mathrm{acac})_{4}\left(\mathrm{H}_{2} \mathrm{O}\right)_{2}\right]$ are 3.245(1) and 2.232(1) $\AA$ for $\mathrm{Co}(1)-\mathrm{Co}(1 \mathrm{~A})$ and $\mathrm{Co}(2)-\mathrm{Co}(2 \mathrm{~A})$, respectively. All of

Table 3

Selected bond lengths $(\AA)$ and angles $\left(^{\circ}\right)$ for 6

\begin{tabular}{lclr}
\hline $\begin{array}{l}\text { Bond lengths } \\
\mathrm{Co}-\mathrm{O}(1)\end{array}$ & $1.955(3)$ & $\mathrm{Co}-\mathrm{Cl}(2)$ & $2.2574(12)$ \\
$\mathrm{Co}-\mathrm{O}(2) \# 1$ & $1.957(3)$ & $\mathrm{Co}-\mathrm{Cl}(1)$ & $2.2595(12)$ \\
Bond angles & & & \\
$\mathrm{O}(1)-\mathrm{Co}-\mathrm{O}(2) \# 1$ & $131.78(11)$ & $\mathrm{O}(1)-\mathrm{Co}-\mathrm{Cl}(1)$ & $105.91(9)$ \\
$\mathrm{O}(1)-\mathrm{Co}-\mathrm{Cl}(2)$ & $97.49(9)$ & $\mathrm{O}(2) \# 1-\mathrm{Co}-\mathrm{Cl}(1)$ & $97.39(9)$ \\
$\mathrm{O}(2) \# 1-\mathrm{Co}-\mathrm{Cl}(2)$ & $105.94(9)$ & $\mathrm{Cl}(2)-\mathrm{Co}-\mathrm{Cl}(1)$ & $120.73(5)$ \\
\hline
\end{tabular}

Symmetry transformations used to generate equivalent atoms: \# 1 $-x+1 / 2, y-1 / 2,-z+1 / 2$. 


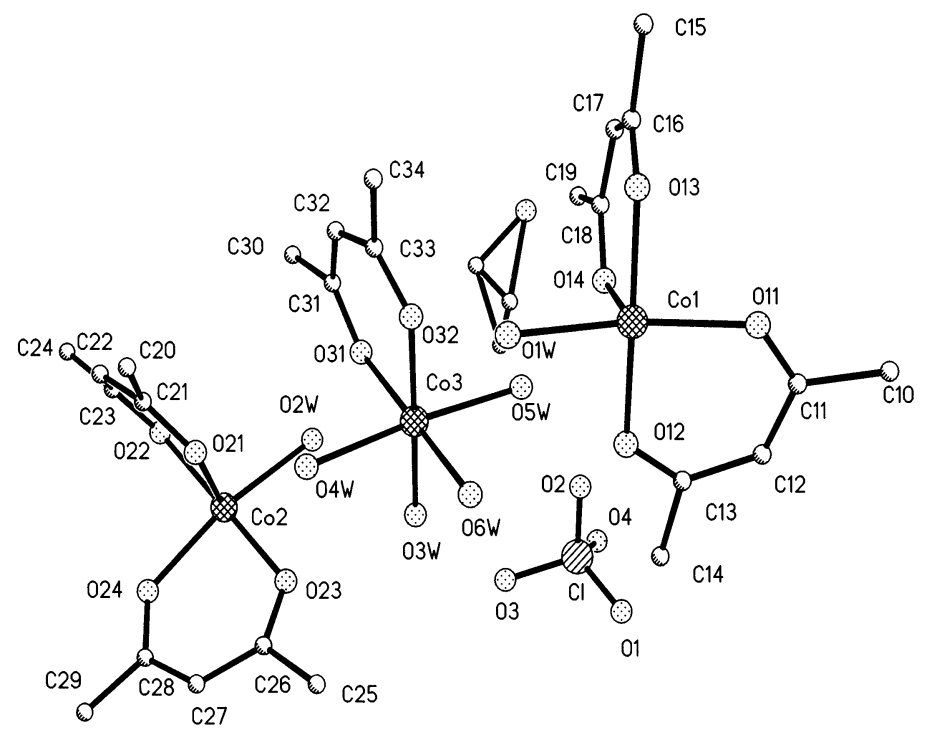

Fig. 6. Asymmetric unit of $\left[\mathrm{Co}_{2}(\mathrm{acac})_{4}\left(\mathrm{H}_{2} \mathrm{O}\right)_{2}\right]\left[\mathrm{Co}(\mathrm{acac})\left(\mathrm{H}_{2} \mathrm{O}\right)_{4}\right] \mathrm{ClO}_{4} \cdot \mathrm{EtOH}(\mathbf{8})$.

the water molecule hydrogen atoms are involved in hydrogen-bonding. The cobalt complexes are linked into dimer-monomer-dimer $\mathrm{H}$-bonded chains which in turn are linked by perchlorate and ethanol.

The asymmetric unit of the mixed ligand complex 9 contains one $\left[\mathrm{Co}(\mathrm{acac})_{2}( \pm) \mathrm{DCH}\right]^{+}$cation and one perchlorate anion (Fig. 8, Table 5). The cobalt(III) ion is six-coordinate and is ligated by two cisoid $\mathrm{acac}^{-}$ions and a neutral $\mathrm{DCH}$ molecule. The $\mathrm{Co}-\mathrm{O}$ (acac) bond distances in $\mathbf{9}$ are notably shorter than those in the $\mathrm{Co}(\mathrm{II})$ complex 8. Apart from the weak hydrogen bond between one of the coordinated amine groups and the

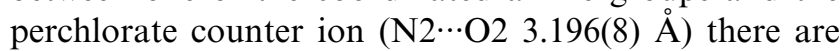
no other striking interionic interactions.

In conclusion, it is seen that in the absence of a metal ion, trans $-( \pm) \mathrm{DCH}$ reacts with acacH (1:2.5 mole ratio) to form the bisoxoenamine condensation product, boe (1). The $\mathrm{Co}(\mathrm{II})$ salts, $\mathrm{CoCl}_{2} \cdot 6 \mathrm{H}_{2} \mathrm{O}$ and $\mathrm{Co}\left(\mathrm{ClO}_{4}\right)_{2} \cdot 6 \mathrm{H}_{2} \mathrm{O}$, react with trans $-( \pm) \mathrm{DCH}$ in air to give complexes containing the oxidised $\mathrm{Co}(\mathrm{III})$ ion, $\left[\mathrm{Co}(( \pm) \mathrm{DCH})_{3}\right]^{3+}$. This ion does not react with added acacH to give a Schiff base complex. Mixtures of complexes are obtained from one-pot reactions involving trans $-( \pm) \mathrm{DCH}$, a simple $\mathrm{Co}(\mathrm{II})$ salt and acacH (1:1:2.5 mole ratio). When $\mathrm{CoCl}_{2} \cdot 6 \mathrm{H}_{2} \mathrm{O}$ is used, the mixed-ligand $(\mathrm{DCH} /$ chloride) $\mathrm{Co}(\mathrm{II})$ complex $[\mathrm{Co}(( \pm)$ $\mathrm{DCH}) \mathrm{Cl}_{2}$ ] (4) precipitates first and, after a period of weeks a myriad of complexes, $(\operatorname{diazH})_{2}\left[\mathrm{CoCl}_{4}\right](5)$, $\left[\mathrm{Co}(\mathrm{boe}) \mathrm{Cl}_{2}\right]_{n}(6)$ and $\left[\mathrm{Co}(\mathrm{acac})_{3}\right](7)$, co-crystallise from the mother liquor. The interesting feature of $\mathbf{5}$ is the diazepinium cation, diazH $\mathrm{H}^{+}$, formed from the 1:1 cyclisation of trans $-( \pm) \mathrm{DCH}$ and acacH. These diazepinium cations act as counterions for the $\mathrm{Co}(\mathrm{II})$ complex ion, $\left[\mathrm{CoCl}_{4}\right]^{2-}$. Complex 6 indicates formation of the bisoxoenamine ligand which ligates neighbouring
Co(II) centre via its carbonyl oxygen atoms. Complex 7 comprises only $\mathrm{acac}^{-}$bidentate ligands chelated to an oxidised $\mathrm{Co}(\mathrm{III})$ centre. Using $\mathrm{Co}\left(\mathrm{ClO}_{4}\right)_{2} \cdot 6 \mathrm{H}_{2} \mathrm{O}$ in the reaction with trans $-( \pm) \mathrm{DCH}$ and acacH gives, again, a mixture of products. Complexes 7, $\left[\mathrm{Co}_{2}(\mathrm{acac})_{4}\left(\mathrm{H}_{2} \mathrm{O}\right)_{2}\right]-$ $\left[\mathrm{Co}(\mathrm{acac})\left(\mathrm{H}_{2} \mathrm{O}\right)_{4}\right] \mathrm{ClO}_{4} \cdot \mathrm{EtOH} \quad(8)$ and $\left[\mathrm{Co}(\mathrm{acac})_{2}( \pm)\right.$ $\mathrm{DCH} \mathrm{ClO}_{4}(\mathbf{9})$ co-crystallise. Complexes 7 and 8 each contain $\mathrm{acac}^{-}$ligands (no DCH and no $\mathrm{DCH} / \mathrm{acacH}$ condensation products) and the metal centres are $\mathrm{Co}(\mathrm{III})$ and $\mathrm{Co}(\mathrm{II})$, respectively. Both $\mathrm{acac}^{-}$and neutral $( \pm) \mathrm{DCH}$ ligands chelate to the oxidised $\mathrm{Co}(\mathrm{III})$ centre in 9. The major difference between using $\mathrm{CoCl}_{2} \cdot 6 \mathrm{H}_{2} \mathrm{O}$ and $\mathrm{Co}\left(\mathrm{ClO}_{4}\right)_{2} \cdot 6 \mathrm{H}_{2} \mathrm{O}$ in reactions involving $( \pm) \mathrm{DCH}$ and $\mathrm{acacH}$ is that no $\mathrm{DCH} / \mathrm{acacH}$ condensation products are identified in the product mixtures when the perchlorate salt is employed.

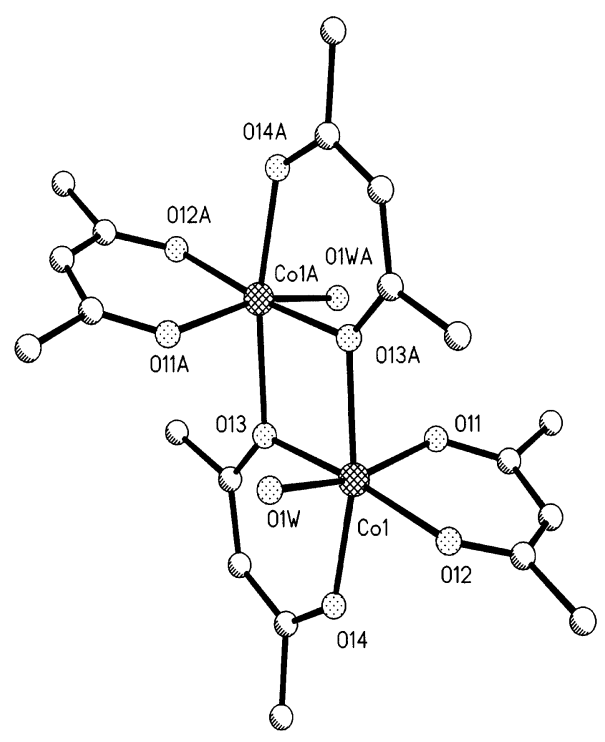

Fig. 7. One of the two independent $\left[\mathrm{Co}_{2}(\mathrm{acac})_{4}\left(\mathrm{H}_{2} \mathrm{O}\right)_{2}\right]$ molecules in $\mathbf{8}$. 
Table 4

Selected bond lengths $(\AA)$ and angles $\left(^{\circ}\right)$ for 8

Bond lengths

$\mathrm{Co}(1)-\mathrm{O}(11)$

$\mathrm{Co}(1)-\mathrm{O}(12)$

$\mathrm{Co}(1)-\mathrm{O}(13)$

$\mathrm{Co}(1)-\mathrm{O}(14)$

$\mathrm{Co}(1)-\mathrm{O}(1 \mathrm{~W})$

$\mathrm{Co}(1)-\mathrm{O}(13) \# 1$

$\mathrm{Co}(1)-\mathrm{Co}(1) \# 1$

$\mathrm{Co}(2)-\mathrm{O}(23)$

$\mathrm{Co}(2)-\mathrm{O}(24)$

$\mathrm{Co}(2)-\mathrm{O}(22)$

Bond angles

$\mathrm{O}(11)-\mathrm{Co}(1)-\mathrm{O}(12)$

$\mathrm{O}(13)-\mathrm{Co}(1)-\mathrm{O}(14)$

$\mathrm{O}(14)-\mathrm{Co}(1)-\mathrm{O}(13)$ \# 1

$\mathrm{O}(23)-\mathrm{Co}(2)-\mathrm{O}(24)$

$2.037(2)$
$2.047(2)$
$2.058(2)$
$2.064(2)$
$2.099(2)$
$2.164(2)$
$3.2449(10)$
$2.039(2)$
$2.041(2)$
$2.055(2)$

\section{$\mathrm{Co}(2)-\mathrm{O}(21)$}

$\mathrm{Co}(2)-\mathrm{O}(2 \mathrm{~W})$

$\mathrm{Co}(2)-\mathrm{O}(22) \# 2$

$\mathrm{Co}(3)-\mathrm{O}(32)$

$\mathrm{Co}(3)-\mathrm{O}(3 \mathrm{~W})$

$\mathrm{Co}(3)-\mathrm{O}(31)$

$\mathrm{Co}(3)-\mathrm{O}(6 \mathrm{~W})$

$\mathrm{Co}(3)-\mathrm{O}(5 \mathrm{~W})$

$\mathrm{Co}(3)-\mathrm{O}(4 \mathrm{~W})$

89.71(10) $\mathrm{O}(22)-\mathrm{Co}(2)-\mathrm{O}(21) \quad 88.55(9)$

$88.99(10) \quad \mathrm{O}(21)-\mathrm{Co}(2)-\mathrm{O}(22) \# 2 \quad 167.08(9)$

$167.70(9) \quad \mathrm{O}(32)-\mathrm{Co}(3)-\mathrm{O}(31) \quad 87.17(10)$

89.61(10)
$\mathrm{Co}(2)-\mathrm{Co}(2) \# 2$

Symmetry transformations used to generate equivalent atoms: \# 1 $-x,-y,-z ; \# 2-x+1,-y+1,-z+1$.

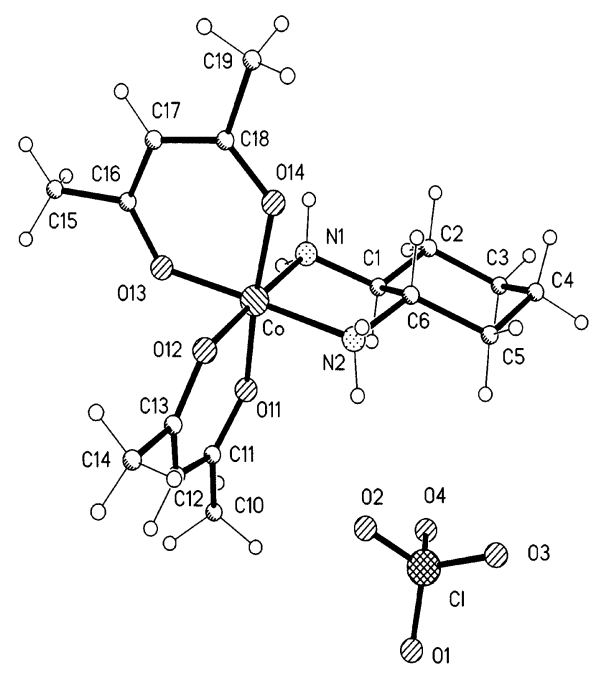

Fig. 8. Asymmetric unit of $\left[\mathrm{Co}(\operatorname{acac})_{2}( \pm) \mathrm{DCH}^{2} \mathrm{ClO}_{4}(9)\right.$.

Table 5

Selected bond lengths $(\AA)$ and angles $\left(^{\circ}\right)$ for 9

\begin{tabular}{llll}
\hline $\begin{array}{l}\text { Bond lengths } \\
\mathrm{Co}-\mathrm{O}(11)\end{array}$ & $1.877(4)$ & $\mathrm{Co}-\mathrm{O}(12)$ & $1.892(4)$ \\
$\mathrm{Co}-\mathrm{O}(14)$ & $1.882(4)$ & $\mathrm{Co}-\mathrm{N}(2)$ & $1.936(5)$ \\
$\mathrm{Co}-\mathrm{O}(13)$ & $1.886(4)$ & $\mathrm{Co}-\mathrm{N}(1)$ & $1.941(5)$ \\
& & & \\
Bond angles & & & \\
$\mathrm{O}(14)-\mathrm{Co}-\mathrm{O}(13)$ & $96.93(19)$ & $\mathrm{N}(2)-\mathrm{Co}-\mathrm{N}(1)$ & $86.7(2)$ \\
$\mathrm{O}(11)-\mathrm{Co}-\mathrm{O}(12)$ & $96.67(19)$ & & \\
\hline
\end{tabular}

\section{Experimental}

Chemicals were purchased from commercial sources and used without further purification. Infrared spectra were recorded as $\mathrm{KBr}$ discs in the region 4000-400 $\mathrm{cm}^{-1}$ on a Nicolet Impact 400D FT-IR Spectrometer. Electron impact mass spectra were measured using a
Kratos Analytical Profile instrument. Elemental analyses were carried out by the Microanalytical Laboratory, Chemistry Department, National University of Ireland, Cork, Ireland.

\section{1. boe (1)}

To a solution of trans $-( \pm$ )-DCH $(1.07 \mathrm{~g}, 9.37 \mathrm{mmol})$ in ethanol $\left(20 \mathrm{~cm}^{3}\right)$ was added acacH $(2.37 \mathrm{~g}, 23.67$ $\mathrm{mmol}$ ) and the resulting solution allowed to stir for 24 $\mathrm{h}$. The mixture was rotary evaporated to dryness and the yellow solid recrystallised from hot ethanol. Colourless crystals of the product slowly formed and some of these in their mother liquor were used for X-ray structure determination. The remainder of the product was filtered from the mother liquor and washed with two small portions of cold ethanol. After a final washing with diethyl ether the solid was allowed to air-dry. The compound was soluble in ethanol and in chloroform and was insoluble in water. Yield $1.77 \mathrm{~g}(68 \%)$. Anal. Found: C, 69.02; H, 9.45; N, 10.20. Calc.: C, 69.03; H, 9.41; N, $10.07 \%$. m.p. $146-148{ }^{\circ} \mathrm{C}$. IR: 3076,2944 , 2856, 1603, 1576, 1300, 1150, 1119, 1026, 995, 816, 741 $\mathrm{cm}^{-1}$. Mass spec.: $m / z=279,278,179,136$ (base peak).

\section{2. $\left[\mathrm{Co}(( \pm) \mathrm{DCH})_{3}\right] \mathrm{Cl}_{3} \cdot \mathrm{H}_{2} \mathrm{O}$ (2)}

To a stirred solution of trans $-( \pm)$ DCH (3.21 g, 28.11 mmol) in ethanol $\left(20 \mathrm{~cm}^{3}\right)$ was added a solution of $\mathrm{CoCl}_{2} \cdot 6 \mathrm{H}_{2} \mathrm{O}(2.23 \mathrm{~g}, 9.37 \mathrm{mmol})$ in ethanol $\left(10 \mathrm{~cm}^{3}\right)$. An immediate blue to green to light red colour change occurred and the light-red product precipitated. The mixture was stirred for $0.5 \mathrm{~h}$, filtered and then washed with several portions of cold ethanol. After a final washing with diethyl ether the solid was allowed to air-dry. Yield $2.17 \mathrm{~g}$ (44\%). Anal. Found: C, 41.37; H, 8.34; N, 15.31. Calc.: C, 41.11; H, 8.43; N, 15.99\%. IR: $3440,3140,3070,2940,2860,1590,1450,1159,1059$, $1030 \mathrm{~cm}^{-1}$.

\section{3. $\left[\mathrm{Co}(( \pm) \mathrm{DCH})_{3}\right]\left(\mathrm{ClO}_{4}\right)_{3}(3)$}

This red solid was prepared by a similar procedure to that employed for the synthesis of $[\mathrm{Co}(( \pm)$ $\left.\mathrm{DCH})_{3}\right] \mathrm{Cl}_{3} \cdot \mathrm{H}_{2} \mathrm{O}$, but using $\mathrm{Co}\left(\mathrm{ClO}_{4}\right)_{2} \cdot 6 \mathrm{H}_{2} \mathrm{O}$ instead of $\mathrm{CoCl}_{2} \cdot 6 \mathrm{H}_{2} \mathrm{O}$. Yield (25\%). Anal. Found: C, 31.64; H, 6.15; N, 11.84. Calc.: C, 30.89; H, 6.05; N, 12.01\%. IR: $3498,3260,2935,2862,1561,1452,1252,1079$, 922, $769,625 \mathrm{~cm}^{-1}$.

\section{4. $\left[\mathrm{Co}(( \pm) \mathrm{DCH}) \mathrm{Cl}_{2}\right](\mathbf{4}),(\operatorname{diazH})_{2}\left[\mathrm{CoCl}_{4}\right](\mathbf{5})$, $\left[\mathrm{Co}(\mathrm{boe}) \mathrm{Cl}_{2}\right]_{n}$ (6) and $\left[\mathrm{Co}(\mathrm{acac})_{3}\right]$ (7)}

To a stirred solution of trans $-( \pm) \mathrm{DCH}(1.07 \mathrm{~g}, 9.37$ mmol $)$ in ethanol $\left(20 \mathrm{~cm}^{3}\right)$ was added $\mathrm{CoCl}_{2} \cdot 6 \mathrm{H}_{2} \mathrm{O}(2.23$ 
g, $9.38 \mathrm{mmol})$ and acacH $(2.37 \mathrm{~g}, 23.67 \mathrm{mmol})$. As the mixture was stirred over a $3 \mathrm{~h}$ period it became dark blue in colour and the green powder 4 precipitated. Complex 4 was filtered off, washed with two small portions o $\mathrm{f}$ ethanol and then diethyl ether. Yield 4 $0.33 \mathrm{~g}(14 \%)$. When the vessel containing the original blue mother liquor was sealed and set aside for 3 weeks, complexes 5, $\mathbf{6}$ and 7 co-crystallised. Single crystals of each of the three complexes were carefully separated from the mixture and subjected to X-ray structural analysis. The remainder of the crystalline solid mixture was filtered off, washed with ethanol and dried in vacuo. Yield of mixture 1.39 g. Anal. Found: C, 31.08; $\mathrm{H}, 5.90 ; \mathrm{N}, 11.66 ; \mathrm{Cl}, 27.37$. Calc. for 4: C, 29.53; H, 5.78; N, 11.48; Cl, 29.05\%. IR: 3460, 3270, 3215, 3140, 2940, 2860, 1580, 1445, 1150, 1135, 1059, $1035 \mathrm{~cm}^{-1}$.

3.5. $\left[\mathrm{Co}(\mathrm{acac})_{3}\right](7),\left[\mathrm{Co}_{2}(\mathrm{acac})_{4}\left(\mathrm{H}_{2} \mathrm{O}\right)_{2}\right]-$

$\left[\mathrm{Co}(\mathrm{acac})\left(\mathrm{H}_{2} \mathrm{O}\right)_{4}\right] \mathrm{ClO}_{4} \cdot \mathrm{EtOH}(\boldsymbol{8})$ and

$\left[\mathrm{Co}(\mathrm{acac})_{2}( \pm) \mathrm{DCH} \mathrm{ClO}_{4}(\mathbf{9})\right.$

trans $-( \pm) \mathrm{DCH}(1.14 \mathrm{~g}, 9.98 \mathrm{mmol})$ was dissolved in ethanol $\left(20 \mathrm{~cm}^{3}\right)$ and added acacH $(2.52 \mathrm{~g}, 25.17$ mmol). Heat was evolved and the light yellow solution was stirred for $10 \mathrm{~min}$. $\mathrm{Co}\left(\mathrm{ClO}_{4}\right)_{2} \cdot 6 \mathrm{H}_{2} \mathrm{O}(3.65 \mathrm{~g}, 9.97$ mmol) was added and the solution immediately turned dark red and more heat was liberated. After standing for a few days 7, 8 and 9 co-crystallised. Single crystals of each were carefully separated and each, suspended in a drop of the mother liquor, were analysed by X-ray crystallography.

\subsection{X-ray crystallography}

Crystal data for complexes $1,5,6,8$ and 9 are summarized in Table 6 . All the data sets were collected on a Bruker SMART diffractometer using Mo $\mathrm{K} \alpha$ radiation $(\lambda=0.71071 \AA)$; 1 was collected at room temperature, the others were collected at 150(2) K. Each structure was solved by direct methods and refined on $F^{2}$ using SHELXTL [17]. All non-hydrogen atoms were refined with anisotropic atomic displacement parameters except for the disordered ethanol solvate and the minor component of the perchlorate disorder in 8. Hydrogen atoms coordinated to carbon were inserted at calculated positions except for those of the ethanol molecule in $\mathbf{8}$, which were not included. Hydrogen atoms bonded to oxygen atoms were located from difference maps and not refined. The positions of the amine protons were calculated for $\mathbf{9}$, but for $\mathbf{1 , 5}$

Table 6

Summary of crystal data, data collection, structure solution and refinement details for complexes 1, 5, 6, 8 and 9

\begin{tabular}{|c|c|c|c|c|c|}
\hline Identification code & 1 & 5 & 6 & 8 & 9 \\
\hline Complex & boe & $(\operatorname{diazH})_{2}\left[\mathrm{CoCl}_{4}\right]$ & {$\left[\mathrm{Co}(\text { boe }) \mathrm{Cl}_{2}\right]_{n}$} & $\begin{array}{l}{\left[\mathrm{Co}_{2}(\mathrm{acac})_{4}\left(\mathrm{H}_{2} \mathrm{O}\right)_{2}\right]-} \\
{\left[\mathrm{Co}(\mathrm{acac})\left(\mathrm{H}_{2} \mathrm{O}\right)_{4}\right] \mathrm{ClO}_{4} \cdot \mathrm{EtOH}}\end{array}$ & {$\left[\mathrm{Co}(\mathrm{acac})_{2}( \pm) \mathrm{DCH}\right] \mathrm{ClO}_{4}$} \\
\hline Empirical formula & $\mathrm{C}_{16} \mathrm{H}_{26} \mathrm{~N}_{2} \mathrm{O}_{2}$ & $\mathrm{C}_{22} \mathrm{H}_{38} \mathrm{Cl}_{4} \mathrm{CoN}_{4}$ & $\mathrm{C}_{16} \mathrm{H}_{26} \mathrm{Cl}_{2} \mathrm{CoN}_{2} \mathrm{O}_{2}$ & $\mathrm{C}_{27} \mathrm{H}_{51} \mathrm{ClCo}_{3} \mathrm{O}_{21}$ & $\mathrm{C}_{16} \mathrm{H}_{28} \mathrm{ClCoN}_{2} \mathrm{O}_{8}$ \\
\hline Formula weight & 278.39 & 559.30 & 408.22 & 923.92 & 470.78 \\
\hline Temperature (K) & $298(2)$ & $150(2)$ & $150(2)$ & $150(2)$ & $150(2)$ \\
\hline Space group & $P \overline{1}$ & $P b c n$ & $C 2 / c$ & $P \overline{1}$ & $C 2 / c$ \\
\hline \multicolumn{6}{|l|}{ Unit cell dimensions } \\
\hline$a(\AA)$ & $8.783(6)$ & $16.811(2)$ & $15.8275(19)$ & $9.5236(6)$ & $15.579(2)$ \\
\hline$b(\AA)$ & $12.703(11)$ & $12.3038(15)$ & $17.263(2)$ & $10.2902(6)$ & $17.623(2)$ \\
\hline$c(\AA)$ & $15.318(12)$ & $12.7329(16)$ & $15.865(2)$ & $23.6481(15)$ & $14.922(2)$ \\
\hline$\alpha\left(^{\circ}\right)$ & $81.36(4)$ & 90 & 90 & $90.6000(10)$ & 90 \\
\hline$\beta\left(^{\circ}\right)$ & $88.74(5)$ & 90 & $119.856(2)$ & $98.5440(10)$ & $91.492(2)$ \\
\hline$\gamma\left({ }^{\circ}\right)$ & $76.85(4)$ & 90 & 90 & $117.2070(10)$ & 90 \\
\hline$Z$ & 4 & 4 & 8 & 2 & 8 \\
\hline $\begin{array}{l}\text { Absorption coefficient } \\
\qquad\left(\mathrm{mm}^{-1}\right)\end{array}$ & 0.074 & 1.075 & 1.207 & 1.353 & 1.014 \\
\hline$F(000)$ & 608 & 1172 & 1704 & 958 & 1968 \\
\hline Crystal size (mm) & $0.62 \times 0.22 \times 0.17$ & $0.33 \times 0.30 \times 0.15$ & $0.25 \times 0.13 \times 0.08$ & $0.45 \times 0.23 \times 0.12$ & $0.23 \times 0.20 \times 0.07$ \\
\hline $2 \theta$ Range $\left({ }^{\circ}\right)$ & $1.34-25.00$ & $2.05-25.00$ & $1.90-25.00$ & $0.87-27.00$ & $1.75-24.00$ \\
\hline Reflections collected & 16189 & 17832 & 9531 & 23079 & 18310 \\
\hline $\begin{array}{l}\text { Independent reflections } \\
\quad\left(R_{\text {int }}\right)\end{array}$ & $5786(0.0629)$ & $2324(0.0757)$ & $3300(0.0759)$ & $8712(0.0533)$ & $3219(0.0994)$ \\
\hline Max/min transmission & $1.00,0.300$ & $0.8554,0.7181$ & $0.9096,0.7524$ & $1.000,0.828$ & $1.000,0.812$ \\
\hline $\begin{array}{l}\text { Data/restraints/ } \\
\text { parameters }\end{array}$ & $5786 / 0 / 381$ & $2324 / 0 / 151$ & $3300 / 0 / 218$ & $8712 / 10 / 496$ & $3219 / 0 / 257$ \\
\hline $\begin{array}{l}\text { Final } R \text { indices } \\
\qquad[I>2 \sigma(I)]\end{array}$ & $\begin{array}{l}R_{1}=0.0623 \\
w R_{2}=0.1416\end{array}$ & $\begin{array}{l}R_{1}=0.0345 \\
w R_{2}=0.0831\end{array}$ & $\begin{array}{l}R_{1}=0.0468 \\
w R_{2}=0.0982\end{array}$ & $\begin{array}{l}R_{1}=0.0463 \\
w R_{2}=0.1135\end{array}$ & $\begin{array}{l}R_{1}=0.0593 \\
w R_{2}=0.1355\end{array}$ \\
\hline$R$ indices (all data) & $R_{1}=0.1143$ & $R_{1}=0.0568$ & $R_{1}=0.0774$ & $R_{1}=0.0793$ & $R_{1}=0.1181$ \\
\hline & $w R_{2}=0.1583$ & $w R_{2}=0.0938$ & $w R_{2}=0.1133$ & $w R_{2}=0.1261$ & $w R_{2}=0.1793$ \\
\hline
\end{tabular}


and $\mathbf{6}$ they were located from difference maps and their positions allowed to refine.

\section{Supplementary material}

Crystallographic data for the structural analysis have been deposited with the Cambridge Crystallographic Data Centre, CCDC Nos. 159657-159661 for the five complexes. Copies of this information may be obtained free of charge from The Director, CCDC, 12 Union Road, Cambridge, CB2 1EZ, UK (fax: + 44-1223336033; e-mail: deposit@ccdc.cam.ac.uk or www: http://www.ccdc.cam.ac.uk).

\section{Acknowledgements}

M. McCann and V. McKee acknowledge receipt of funding from the Enterprise Ireland/British Council Research Visits Scheme.

\section{References}

[1] N.A. Bailey, K.C. Cox, C.P. Falshaw, D.E. Fenton, S.E. Grundy, P. Haigh, C.A. Phillips, T.J. King, J. Chem. Soc., Dalton Trans. (1983) 2241.
[2] (a) D. Lloyd, H.P. Cleghorn, D.R. Marshall, Adv. Heterocycl. Chem. 17 (1974) 1;

(b) D. Lloyd, H.P. Cleghorn, Adv. Heterocycl. Chem. 17 (1974) 27.

[3] The Complete Drug Reference, Consumer Reports Book, 1992 edn., Consumers Union, New York, p 218.

[4] R.F. Jordan, D.G. Black, D.C. Swenson, Acta Crystallogr. Sect. C 54 (1988) 1030.

[5] G.W. H. Potter, M.W. Coleman, A.M. Monro, J. Heterocycl. Chem. 12 (1975) 611.

[6] G. Swarzenbach, K. Lutz, Helv. Chim. Acta 23 (1940) 1139.

[7] M. Gullotti, A. Pasini, P. Fantucci, R. Ugo, R.D. Gillard, Gazz. Chim. Ital. 102 (1972) 855.

[8] E.G. Jager, K. Schuhmann, H. Gorls, Inorg. Chim. Acta 255 (1997) 295.

[9] A.L. Spek, Platon, A Multipurpose Crystallographic Tool, 1980-2000.

[10] D.J. Williams, J.S. Kruger, A.F. McLeroy, A.P. Wilkinson, J.C. Hanson, Chem. Mater. 11 (1999) 2241.

[11] C. Pariya, K. Panneerselvan, C.-S. Chung, T.-H. Lu, Polyhedron 17 (1998) 2555.

[12] C. Pariya, F.-L. Liao, S.-L. Wang, C.-S. Chung, Polyhedron 17 (1998) 547.

[13] D.F. Martin, E.J. Olszewski, Inorg. Synth. 8 (1966) 46.

[14] M. Brisander, S.G. Harris, D. Lloyd, H. McNab, S. Parsons, Chem. Res. 72 (1998) 526.

[15] (a) V.M. Padmanabhan, Proc. Ind. Acad. Sci. A 47 (1958) 329; (b) P.K. Hon, C.E. Pfluger, J. Coord. Chem. 3 (1973) 67;

(c) G.J. Kruger, E.C. Reynhardt, Acta Crystallogr., Sect. B 30 (1974) 822.

[16] (a) F.A. Cotton, R.C. Elder, Inorg. Chem. 4 (1965) 1145; (b) J.B. Ellern, R.O. Ragsdale, Inorg. Synth. 11 (1968) 84.

[17] SHELXTL Version 5.1, Bruker AXS, 1998. 